\title{
HISTOCHEMICAL ANALYSIS OF GASTROINTESTINAL MUCOSUBSTANCES OF FRESH WATER FISH Mastacembelus armatus INFECTED BY HELMINTH PARASITE Circumonco bothrium sp.
}

\author{
Laxmikant B. Dama ${ }^{1 \times 凶}$ and Amjadkhan V. Pathan ${ }^{2 \star 凶}$ \\ ${ }^{1}$ Department of Zoology, D.B.F. Dayanand College of Arts and Science, Solapur, 413002 (M.S.), India \\ 2Department of Zoology, Azad College, Ausa-413520, (M. S.), India \\ Email: southraj@gmail.com; amjadkhanp391@gmail.com; ORCID: 0000-0003-3157-8457 \\ supporting Information
}

\begin{abstract}
Present study was conducted to investigate the histochemical changes induced by Circumonco bothrium sp. in the intestine of freshwater fish Mastacembelus armatus. During present investigations the infection of Circumonco bothrium sp. in Mastacembelus armatus with various histochemical reactions showed localization of localization of carbohydrate, protein, lipid and glycogen. During histochemical study intestine infected by cestodes, the numbers of mucous cells those containing acidic or mixed glycoconjugates were significantly higher than those seen on sections from uninfected fish, which is a protective interaction of the host against parasitic infection. In the current study, a highly significant increase in the number of mucous cells was seen within the infected intestines of Mastacembelus armatus when compared to uninfected counterparts.
\end{abstract}

Keywords: Circumonco bothrium sp., Histochemical, Intestine, Mastacembelus armatus

\section{INTRODUCTION}

The gastrointestinal system is primarily involved in breaking down food for absorption in to the body. It is essentially a muscular tube lined by a mucous membrane which exhibits regional variations reflecting the changing functions of the system from mouth to anus. The Alimentary canal is an organ which is involved in various important physiological functions. It is the primary site of food digestion (absorption) and nutrient uptake.

According to Srivastava (1975) and Chandra et al. (2011), most of the species of helminths in adult stage live in the alimentary canal these parasites have detrimental effects upon fish in more ways than one. Different parts of the cell are biochemically different, they take up specific stains to varying degrees. Histochemical tests are used in an attempt to identify cell and tissue components by virtue of their specific chemical reactions. The alteration in the state of cell constituent can be studied by using histochemical techniques, these techniques helps to analyze not only the localization of carbohydrate, protein, lipid and glycogen etc. but also molecular changes at cellular level. The noteworthy contributions towards the expansion and development of histochemistry are those of Lillie (1954), McManus (1948), Pearse (1968) and Bancroft and Stevens (1992), Sonune (2014). In 2012, Ghosh and Chakrabarti observed the histochemistry of the olfactory rosette of Cyprinus carpio.

The present study includes the Histochemical analysis of gastrointestinal mucosubstances of fresh water fish Mastacembelus armatus infected by helminth parasite Circumonco bothrium sp.

\section{MATERIALS AND METHODS}

\section{Preparation of slides for histochemical studies:}

For histochemical analysis, small fragments from the anterior, middle and posterior parts of infected intestine were used. The infected intestine and normal were cut into small pieces and were fixed in Bouin's fluid. After 48 hours, washed several times with water, dehydrated in graded series of alcohols, cleared in Cedar wood oil and xylene, blocks were made in cavity blocks by usual method. Thick sections were cut with a rotary microtome at 4- 5 micron thick. After removing the wax by xylene, hydration was carried out, dehydrated, cleared in clove oil and xylene and mounted permanently in Canada balsam. Sections were stained with various histochemical staining methods. Best slides or sections were selected and observed under the microscope for histochemical study. Photographs were taken with digital camera Nikon Coolpix L24.

Methods used for histochemical tests were:

1. Periodic Acid-Schiff (PAS) (McManus, 1948)

2. Alpha-amilase-PAS (McManus, 1948)

3. Alcian blue pH 2.5 (Martoja and Martoja-Pierson, 1970)

4. Alcian blue pH 0.4 (Martoja and Martoja-Pierson, 1970) 
5. Congo red (Pearse, 1968)

6. Sudan black B (McManus, 1948)

7. Ferric ferricyonide (Pearse, 1968)

8. Free aldehydes (Sawhney and Randhir Singh, 2014)

All the data of results were tabulated according to color intensity into different grades ranging from + to ++++ Colour index:

$\begin{array}{ll}\text { 1. Strong positive reaction } & ++++ \\ \text { 2. Moderate reaction } & ++ \\ \text { 3. Weak reaction } & + \\ \text { 4. Negative reaction } & -\end{array}$

\section{RESULTS}

During present investigations the infection of Circumonco bothrium sp. in Mastacembelus armatus with different histochemical reactions showed localization of different chemicals. The results on the detection of the different mucins in infected intestine are shown (Figures 1-8).

When the sections of intestines are stained with PAS stain, it was found that uninfected fish showed abundant PAS positive carbohydrates in the brush border of the intestine, whereas a moderate amount was seen intestinal goblet cells. The most evident change observed in parasitized fish with respect to uninfected fish was that the low goblet cells though changes in the intensity of PAS staining were not evident. Lamina propria was slightly PAS positive in both infected and uninfected fish (Figures 1 and 2). When stained with Alcian blue pH 2.5 section of infected showed moderate staining with $A B$ staining, bluish colour with this test suggesting the presence acid mucopolysaccharide content (Figure 3 ). With Alcian blue pH 0.4 section of normal intestine showed sulphated mucins predominant whereas infected intestine showed few sulphated mucins (Figure 4). When stained with Congo red the infected intestine showed extensive deposition of eosinophilic amorphous material (amyloid) in the muscularis mucosa, submucosa, and muscularis propria layers of the intestine (Figure 5). With Sudan black B the normal intestine show the relatively low amount of lipid whereas infected intestine show the relatively high amount of lipid (Figure 6). When stained with Ferric ferricyonide infected intestine with Circumonco bothrium sp. shows moderate iron deposits in the tissue which is the indication of the disease (Figure 7). With Free aldehydes the infected intestine shows PPT whereas normal intestine do not show PPT (Figure 8).

Table 1 - Results of histochemical reactions of normal and infected intestine of freshwater fish Mastacembelus armatus infected with Circumonco bothrium sp.

\begin{tabular}{|c|c|c|c|c|c|c|}
\hline \multirow{3}{*}{$\begin{array}{l}\text { Sr. } \\
\text { No. }\end{array}$} & \multirow{3}{*}{ Stain/Method } & \multicolumn{2}{|c|}{ Intensity } & \multirow{2}{*}{\multicolumn{2}{|c|}{ Inference about mucosubstances }} & \multirow{3}{*}{$\begin{array}{l}\text { Fig. } \\
\text { No. }\end{array}$} \\
\hline & & \multirow{2}{*}{$\begin{array}{c}\text { Normal } \\
\text { intestine }\end{array}$} & \multirow{2}{*}{$\begin{array}{l}\text { Infected } \\
\text { intestine }\end{array}$} & & & \\
\hline & & & & Normal intestine & Infected intestine & \\
\hline 1 & PAS & +++ & ++ & Neutral mucin present & Neutral mucin present & 1 \\
\hline 2 & Alpha-amilase-PAS & ++ & + & Mucin present & Increase mucin & 2 \\
\hline 3 & Alcian - blue pH 2.5 & ++ & +++ & Acidic mucins present & Acidic mucins Increase & 3 \\
\hline 4 & Alcian - blue pH 0.4 & ++ & + & $\begin{array}{l}\text { Sulphated mucins } \\
\text { predominant }\end{array}$ & Few sulphated mucins & 4 \\
\hline 5 & Congo red & ++ & +++ & Amyloid elastic fibres few & Increase Amyloid & 5 \\
\hline 6 & Sudan black B & ++ & +++ & Less lipid & Increase lipid & 6 \\
\hline 7 & Ferric ferricyonide & + & ++ & Less iron deposits & More iron deposits & 7 \\
\hline 8 & Free aldehydes & + & ++ & No PPT & Dark PPT & 8 \\
\hline
\end{tabular}

\section{DISCUSSION}

A heavy mucus production has also been described from several other fish-helminth systems including those detailed by Chambers et al. (2001). The attachment organ of helminth parasites often provokes an inflammatory response within the hosts gastrointestinal tract (Dezfuli et al., 2011). Inflammation is a protective reaction in response to parasitic invasion which results stimulation of specific chemical alterations to the cellular community and tissues at the site of infection. Hur et al. (2013) although the factors that govern mucus discharge are partially defined for mammals, they are not well studied in fish. The present findings are more or less similar to the observations made by Kaur (2014). Who reported the pathological changes mainly enhanced mucus secretion in 
Channa punctatus and Channa striatus infected by cestode, Senga sp. A heavy mucus production has also been described from several other fish-helminth systems including those detailed by Benarjee and Reddy (2006).

Observation of the selected infected slides reveals that average amount of amyloid is present, which stained brownish black in colour when stained with Congo red whereas in normal intestine show the relatively low amount of amyloid. The gastrointestinal tract is typically covered by mucus, the properties of which change in different regions of the alimentary canal (Shephard, 1994). The mucus, which can be considered an aggregate secretion, is produced by mucous cells. Whereas, mucin is glycoproteins within this secretion (Theodoropoulos et al., 2001). There is a high trace of glycogen particularly in the muscularis mucosa, but in infected intestine moderate quantity of glycogen is seen (Sonune, 2014).

There is no complete agreement on the role of excessive mucus secretion which, in the intestines of fish infected with helminths, appears as protective blanket of gel or mucus. Although it has been suggested that increased mucus production in mammals may facilitate the expulsion of intestinal nematodes (Ishikawa et al., 1993), this is not the case in the current Circumonco bothrium sp. and Mastacembelus armatus situation. In the present study Circumonco bothrium sp ensures a secure attachment to the intestinal wall of its host even they crossed the intestine and enters the coelom. Thus it will be suggested that, the main role of mucus is to protect the underlying intestinal mucosa as a physical barrier against the mechanical and biochemical damage induced by parasites (Schroers et al., 2009).
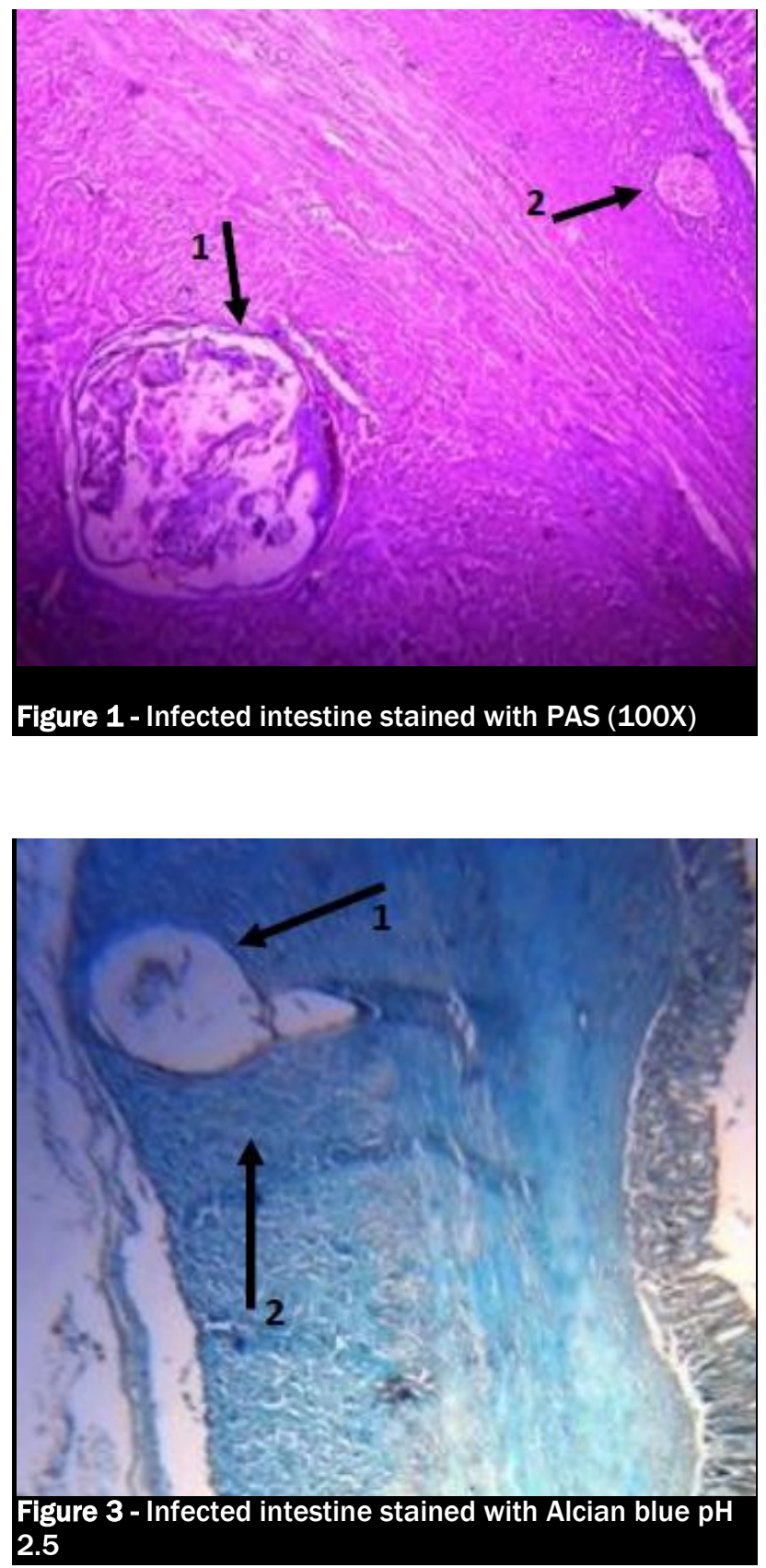
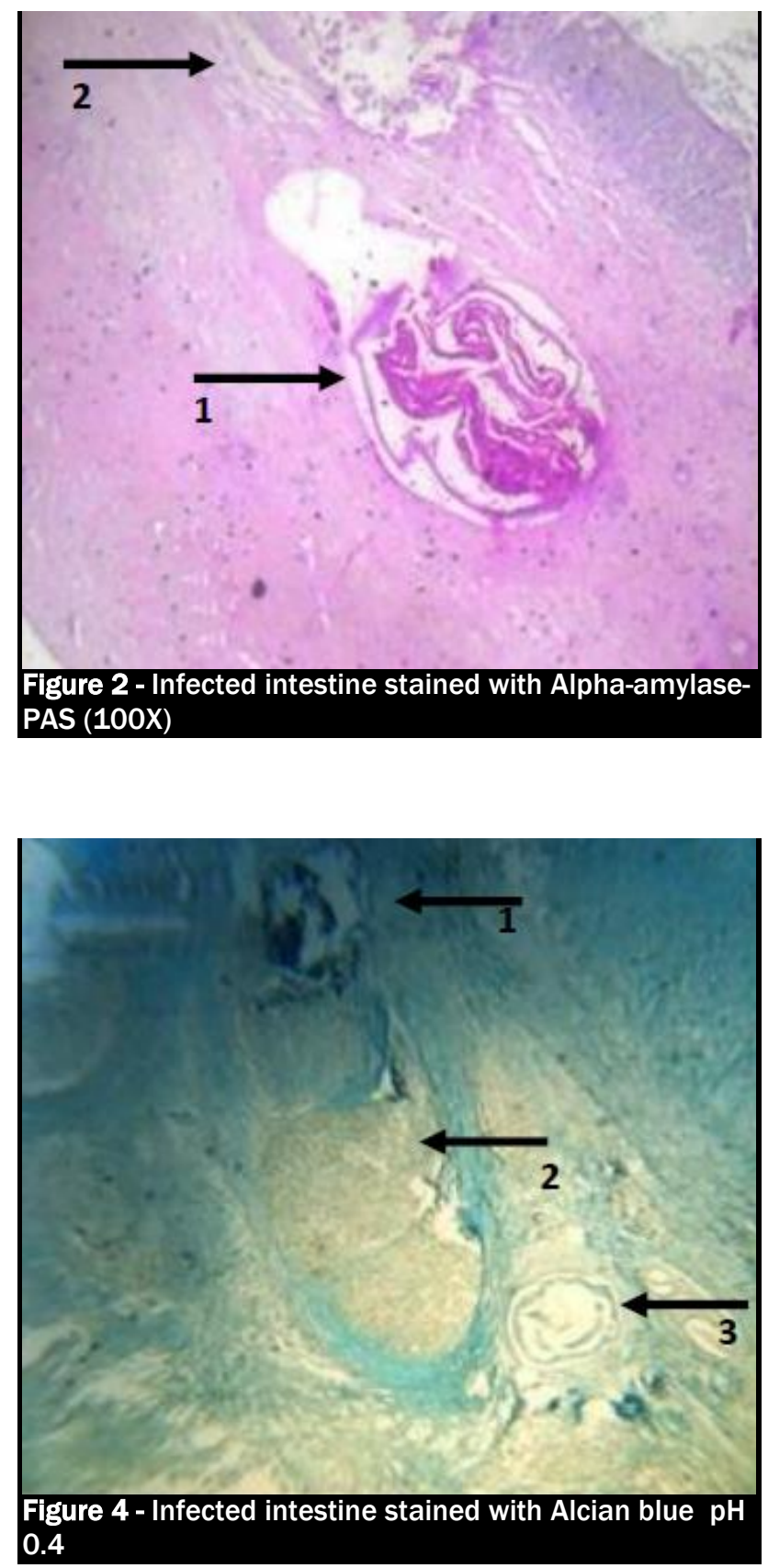

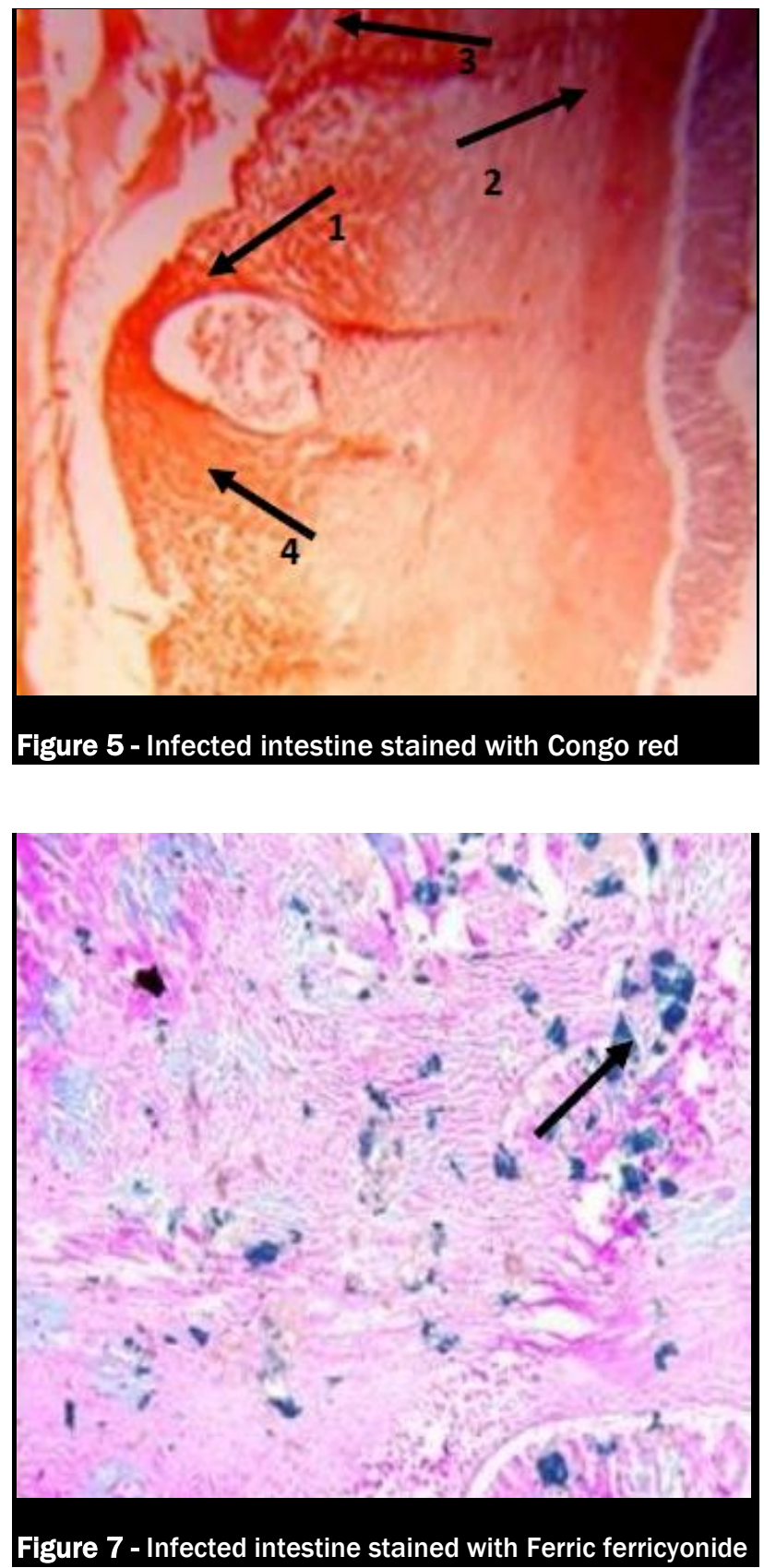
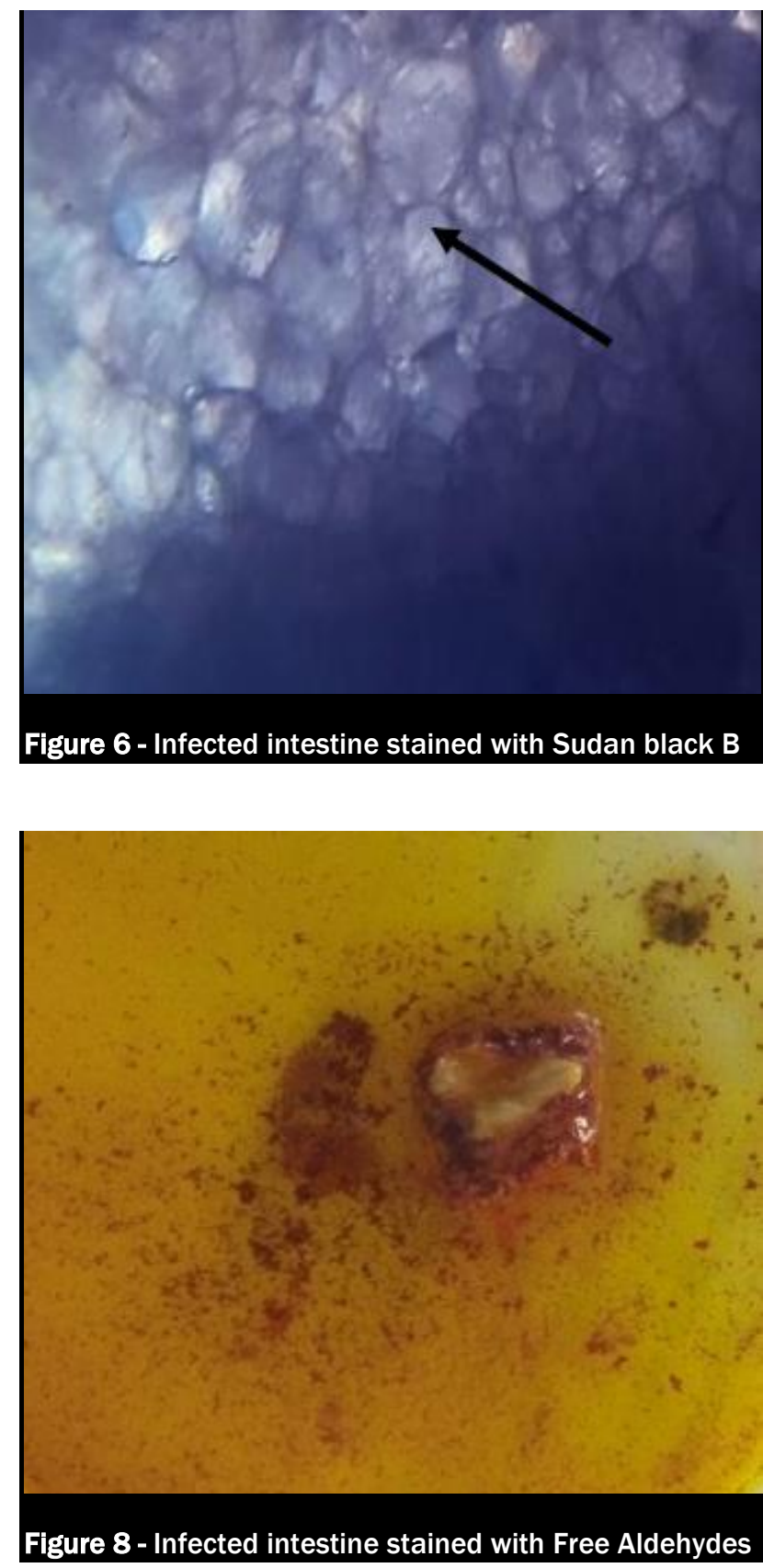

\section{CONCLUSION}

The gastrointestinal tract is typically covered by mucus, the properties of which change in different regions of the alimentary canal. The mucus, which can be considered an aggregate secretion, is produced by mucous cells; mucus, however, differs from mucin which refers to specific glycoproteins within this secretion. Intestinal mucus, which is continuously secreted to renew the coating, is a dynamic system which is coupled to the immune system. An accelerated secretion is characterized by a rapid, massive mucous cell discharge in response to physiologic or pathologic stimuli by the parasite. Moreover, the histochemical investigations provide an insight into the nature of various physiological and pathological processes in the gastrointestinal tract occurred due to parasites. It has been observed that the different constituents are stimulated by particular parasite and particular loss in different organs of the digestive system of the fish studied. Histochemical study may provide a valuable with low cost effective tool for the diagnosis of diseases in histopathology, parasitic investigation and for the researchers in histopathology.

\section{DECLARATIONS}

\section{Corresponding author}

Laxmikant B. Dama is Associate Professor at Dayanand Institutions, Solapur (M.S.), India. In 1998, he completed his Ph.D. in Zoology. His expertise is applied parasitology, fishery science, and his current interests include the isolation of bioactive compounds and to study their effects on animals. Additionally, he is actively involved in writing, editing, and 
reviewing research articles for different journals. His publication list is available on Google Scholar and ORCID. E-mail: amjadkhanp391@gmail.com; ORCID: 0000-0003-3157-8457

Acknowledgement

We thank to Principal, Dayanand College of Arts and Science, Solapur for providing laboratory facilities.

\section{Conflict of interest}

The authors declare they have no competing of interests.

\section{REFERENCES}

Bancroft JD and Stevens A (1992). Theory and Practice of Histological Techniques, 3 rd Edition, Churchill Livingstone, Edinburg, London, Melbourne and New York.

Benarjee G and Laxma Reddy B. (2006). Histopathological and histochemical changes in the liver of Clarias batrachus due to trematode, Euclinostomum heterostomum. Journal of Natcon. 18(2):251-259.

Chambers CB, Carlisle MS, Dove ADM and Cribb TH (2001). A description of Lecithocladium invasor n.sp. (Digenea: Hemiuridae) and the pathology associated with two species of Hemiuridae in acanthurid fish. Parasitology Research, 87:666-73. (Google Scholar; Import into EndNote)

Chandra KJ, Hasan M and Basak SS (2011). Prevalence of Genarchopsis dasus (Digenea: Hemiuridae) in Channa punctatus of Mymensingh. The Bangladesh Veterinarian, 28(1): 47-54. Dol: https://dx.doi.org/10.3329/bvet.v28i1.8813 (Google Scholar; Import into EndNote)

Dezfuli BS, Giari L., Squerzanti A, Lui A, Lorenzoni M. and Sakalli S (2011). Histological damage and inflammatory response elicited by Monobothrium wageneri (Cestoda) in the intestine of Tinca tinca (Cyprinidae). Parasit Vectors, 4(1): 225. DOI: https://dx.doi.org/10.3923/jbs.2013.242.249 (Google Scholar; Import into EndNote)

Ghosh SK. and Chakrabarti P (2012). Histochemical study of the olfactory rosette of Cyprinus carpio (Linnaeus, 1758). Iranian Journal of Fisheries Science, 11(2): 305-314 2012. (Google Scholar; Import into EndNote)

Hur SW, Lee CH, Lee SH, Kim, BH, Kim HB. and Baek HJ (2013). Characterization of cholecystokinin-producing cells and mucus-secreting goblet cells in the blacktip grouper, Epinephelus fasciatus. Tissue Cell, 45: $153-157 . \quad$ D0I: https://dx.doi.org/0.1016/j.tice.2012.10.005 (Google Scholar; Import into EndNote)

Ishikawa N, Horii $\mathrm{Y}$ and Nawa $\mathrm{Y}$ (1993). Immune-mediated alteration of the terminal sugars of goblet cells in the small intestine of Nippostrongylus brasiliensis-infected rats. Immunology, 78(2): 303-307. (Google Scholar; Import into EndNote)

Kaur, P. (2014). Histo-pathological effect of Senga species (Cestode: Pseudophyllidea) in intestine of Piscian hosts. World Journal of Pharmacy and Pharmaceutical Sciences (WJPPS), 3(10), 1506-1513. (Google Scholar; Import into EndNote)

Lillie RD and Harold M Fullmer (1954). Histopathologic technique and practical histochemistry. McGraw Hill Publication, USA. (Google Scholar; Import into EndNote)

Martoja R and Martoja-Pierson M (1970). Tecnicas de histologia animal. Toray-Masson S.A., Barcelona. 176-208. (Google Scholar; Import into EndNote)

McManus JFA (1948). Histological and histochemical uses of periodic acid. Stain Technology. 23: 99-108. (Google Scholar; Import into EndNote)

Pearse AGE (1968). Histochemistry: Theoretical and Applied. Churchill, London. Vol. 1. (Google Scholar; Import into EndNote)

Sawhney SK and Randhir Singh (2014). Introductory practical biochemistry. Tenth reprint. Narosa publications, Hariyana, Hisar.

Schroers V, van der Marel M, Neuhaus H, and Steinhagen D (2009). Changes of intestinal mucus glycoproteins after preoral application of Aeromonas hydrophila to common carp (Cyprinus carpio). Aquaculture, 288(3-4):184-9. (Google Scholar; Import into EndNote)

Shephard KL (1994). Function for fish mucus. Reviews in Fish Biology and Fisheries, 4(4): 401-429. (Google Scholar; Import into EndNote)

Sonune MB (2014). Glycogen content of some fish parasites (Cestodes) from West Coast of India. Bioscience Discovery, 5(1): 32-34. (Google Scholar; Import into EndNote)

Srivastava CB (1975). Fish pathological studies in India- A brief Review Dr. B.S. Chauhan Comm. Vol. pp. 349-358. (Google Scholar; Import into EndNote)

Theodoropoulos G, Hicks SJ, Corfield AP, Miller G, and Carrington SD (2001). The role of mucins in host-parasite interactions: Part II Helminth parasites. Trends in Parasitology, 17(3): 130-135. DOI: https://dx.doi.org/10.1016/S0169-4758(00)01773-7 (Google Scholar; Import into EndNote) 